Journal of Applied Biology and Biotechnology Vol. 3 (05), pp. 031-034, Sep-Oct, 2015

Available online at http://www.jabonline.in

DOI: $10.7324 / \mathrm{JABB} .2015 .3506$

(c) $\mathrm{EY}$-NC-SA

\title{
Production and Characterization of Alkaline Phosphatase Produced by Bacillus Species
}

\author{
Suganya Kannaiyram ${ }^{1}$, Ravikumar Vedhachalam ${ }^{1 *}$, Murugan Thanigaimalai ${ }^{2}$ \\ ${ }^{1}$ Department of Microbiology, Indo-American College, Cheyyar, Tamil Nadu, India. \\ ${ }^{2}$ Departmrnt of Biomedical Engineering, Noorul Islam University, Kumaracoil, Tamil Nadu, India.
}

\section{ARTICLE INFO}

Article history:

Received on: 04/08/2015

Revised on: 21/08/2015

Accepted on: 14/09/2015

Available online: 22/10/2015

Key words:

Bacterial enzyme, Alkaline

Phosphatase, Bacillus sp. and

SDS-PAGE.

\section{INTRODUCTION}

Alkaline Phosphatase (EC 3.1.3.1) enzyme hydrolyzes the phosphomonoesters from number of organic molecules like ribonucleotides, deoxy-ribonucleotides, proteins, alkaloids, phosphate esters and anhydrides of phosphoric acid [1]. Alkaline Phosphatase is a metallodependent enzyme [2] which shows its catalytic activity optima at alkaline $\mathrm{pH}$ [3]. The wide distribution of alkaline phosphatase in nature, ranging from bacteria to man, indicates that alkaline phosphatase are ubiquitous and involved in fundamental biochemical processes. It can be isolated from variety of microorganisms including Escherichia coli [4], Pseudomonas [5], Aerobactor [6] and Bacillus species [7]. In all bacteria, alkaline phosphatase is found in the periplasmic membrane which is external to the cell membrane of bacteria [8]. Very little work has been done with respect to extracellular production of alkaline phosphatase in genus Bacillus. Hulett et al. [9] investigated the extracellular production of alkaline phosphatase in Bacillus licheniformis which shows that it synthesizes 10 times more alkaline phosphatase activity than is reported for other Bacillus species [10]. However, the extracellular production of alkaline phosphatase has been studied in Micrococcus sodonensis [11], Pseudomonas species [12], Alkalophilic bacterium [13] and

\footnotetext{
* Corresponding Author

Ravikumar Vedhachalam, Department of Microbiology,

Indo-American College, Cheyyar, Tamil Nadu, India.

Email:ravikumar.vd@gmail.com
}

Arthobacter [14]. Bacillus species produce alkaline phosphatase when phosphate becomes growth limiting as well as during sporulation, when phosphate supplies are abundant. Alkaline phosphatase of Bacillus licheniformis and Bacillus subtilis is located intracellular and extracellular. It has been shown that culturing conditions significantly affect both the distribution and the amount of synthesis of alkaline phosphatase [15]. Intracellular production of alkaline phosphatase is quite complex and expensive process in comparison to extracellular. This statement is supported by the study of Hulett et al. [9] which explained that extracellular alkaline phosphatase gave higher specific activity than intracellular alkaline phosphatase is because of short and simple steps of purification. Thus, the present studies are proposed to be conducted for the isolation and characterization of extracellular alkaline phosphatase from Bacillus species isolated from rocky soil.

\section{MATERIALS AND METHODS}

\subsection{Soil sample}

Soil sample $(4-5 \mathrm{~g})$ was collected from white rocky place near Vandhavasi at a depth of $2-5 \mathrm{~cm}$ and transferred to a clean polyethylene bags. The samples were further air dried at room temperature and taken for bacterial isolation.

\subsection{Isolation of bacterial strains}

$1 \mathrm{~g}$ of each collected soil was suspended in $100 \mathrm{ml}$ of saline. Then incubated in an orbital shaker incubator at $28^{\circ} \mathrm{C}$ with shaking at $200 \mathrm{rpm}$ for $30 \mathrm{~min}$. Mixtures were allowed to settle, and serial dilution was made up to $10^{-5}$ using sterile saline water and agitated 
with the vortex at maximum speed. An aliquot of $0.1 \mathrm{ml}$ of each dilution from $10^{-2}$ to $10^{-5}$ was taken and spread evenly over the surface of Nutrient agar medium. The inoculated plates were incubated at room temperature for 24-48 and observed for bacterial growth.

\subsection{Screening of Alkaline phosphatase activity}

Screening test for alkaline phosphatase production was done by using modified Pikovskaya's Agar method. The isolated different colonies were inoculated on Pikovskaya's agar plate, incubated at $37^{\circ} \mathrm{C}$ for $3-5$ days to confirm positive activity by the formation of clear halos around the colonies [16].

\subsection{Characterization and identification of strains}

Pure culture of positive isolates was maintained on nutrient agar slant containing $2 \%$ agar and $\mathrm{pH}$ was adjusted to 7.0. It was identified by physiological (colony morphology, colour, growth $\mathrm{pH}$, temperature and motility), staining techniques (grams stain \& Spore stain) and standard biochemical tests (catalase, oxidase, Methyl red, Voges proscauer, Citrate, TSI, Urease, starch hydrolysis and sugar fermentation).

\subsection{Enzyme production}

Cultures used for enzyme production were grown at $37^{\circ} \mathrm{C}$ for 24 hours shaking $(180 \mathrm{rpm})$ in modified minimal essential media (MEM) containing Calcium phosphate as a substrate along with casein, starch and glucose in different concentrations was added to study the regulation of phosphatase synthesis. The enzyme production was carried out in $250 \mathrm{ml}$ of Erlenmeyer flask containing $50 \mathrm{ml}$ of fermentation medium. The flask was incubated at $37^{\circ} \mathrm{C}$ for $2-5$ days under shaking conditions and observed for subsequent intervals [16].

\subsection{Protein Determination and Enzyme Assay}

Protein concentration of the enzyme was estimated by Lowery et al. [17] method and absorbance determined at $660 \mathrm{~nm}$ by using bovine serium albumin (BSA) as standard. For APase assay, a mixture of $0.2 \mathrm{ml}$ of enzyme preparation and $2.0 \mathrm{ml}$ of a solution of sodium p-nitrophenyl phosphate $(0.2 \mathrm{mg} / \mathrm{ml}$ in $0.1 \mathrm{M}$ Tris-hydrochloride buffer, $\mathrm{pH} 9.5$ ) was incubated at $40^{\circ} \mathrm{C}$ for an appropriate time (usually $10 \mathrm{~min}$ ), the reaction was stopped by addition of $0.2 \mathrm{ml}$ of $13 \% \mathrm{~K}_{2} \mathrm{HPO}_{4}$, and the optical density of the incubated mixture was determined at $420 \mathrm{~nm}$.

\subsection{Purification of enzyme}

The bacterial cell free fermented media was collected and subjected to different steps of purification. It was saturated to $75 \%$ with 2-propanol at a flow rate of $3 \mathrm{ml} / \mathrm{min}$ (kept at 0 to $-4^{\circ} \mathrm{C}$ ) under continuous stirring. The mixture was allowed to stand at $20^{\circ} \mathrm{C}$ for 2 hours and centrifuged for $15 \mathrm{~min}$ at $13000 \mathrm{rpm}$ and $0^{\circ} \mathrm{C}$. The precipitate was then dissolved in $0.1 \mathrm{M}$ Borax- $\mathrm{HCl}, \mathrm{pH}$ 7.2 and dialysed twice against $0.03 \mathrm{M}$ Tris- $\mathrm{HCl}$ buffer, $\mathrm{pH}$ 7.8.The Crude enzyme solutions obtained after dialysis were loaded on Sephadex G-200 columns for further partial purification, Fraction of $6 \mathrm{ml}$ was collected throughout with a flow rate of $15 \mathrm{ml} / \mathrm{hours}$ [18].

\subsection{Molecular Mass Determination}

SDS PAGE was performed according to the Laemmli [19] with the 4\% Acrylamide stacking gel and 10\% Acrylamide separating gel to determine the molecular mass and purity of protein. The sample was treated with sample buffer and boiled at $100{ }^{\circ} \mathrm{C}$ for 3 minutes and loaded onto the gel. A voltage of $150 \mathrm{~V}$ was applied and the gels were left running for 45 minutes to achieve sufficient migration. Proteins were visualized by staining the gel with Coomassie blue G-250 and the molecular weight of alkaline phosphatase was determined by comparing with molecular weight markers.

\subsection{Enzyme Characterization}

The optimum $\mathrm{pH}$, temperature of the enzyme was measured. The effects of substrate concentration, inhibitors and metal concentration of enzyme were also studied [18].

\section{RESULTS AND DISCUSSION}

In this study, Bacillus species was isolated from soil collected near Vandhavasi, Tiruvannamalai district. Soil is contains great diversity of bacterial populations, with many of organisms belonging to groups for which no cultivated representatives are known. Thus, the soil is an excellent source for unknown microorganisms and it has been studied that Bacillus genus is most frequently isolated from soil [20]. As the microorganisms have been known to produce specific enzymes, secondary metabolites, single cell proteins of economic benefits. The gram-positive species Bacillus are well known for its high capacity to secrete proteins, both in its natural habitat and in biotechnological applications.

\subsection{Characterization and identification of strains}

The potential strain was identified by physiological (colony morphology, colour, growth $\mathrm{pH}$, temperature and motility), staining techniques (grams stain \& Spore stain) and standard biochemical tests (catalase, oxidase, Methyl red, Voges proscauer, Citrate, TSI, Urease, starch hydrolysis and sugar fermentation). After the all tests were done, the strain was rather identified using the Bergey's Manual of Determinative Bacteriology. Based on the above results (Table 1), the isolated strain is probably identified as Bacillus sp.

Table 1: Characterization of isolated strains

\begin{tabular}{cll}
\hline SL. No. & Characterization & Result/Inference \\
\hline 1 & Source of strain & Soil \\
2 & Growth condition & Aerobic \\
3 & Temperature & $28-30^{0} \mathrm{C}$ \\
4 & pH & $7 \pm 0.2$ \\
5 & Colony morphology on NA & Raised, Dirty white \\
6 & Gram reaction & + ve \\
7 & Cell morphology & Rods \\
8 & Arrangements & Single/paired \\
9 & Spore & - \\
\hline
\end{tabular}




\begin{tabular}{lll}
\hline 10 & Motility & - \\
11 & Catalase & + \\
12 & Oxidase & + \\
13 & Starch hydrolysis & + \\
14 & Casein hydrolysis & + \\
15 & Indole & - \\
16 & Methyl red & + \\
17 & Voges proscauer & - \\
18 & Citrate test & - \\
19 & Urease test & - \\
& Sugar fermentation test & + \\
20 & Glucose & + \\
21 & Sucrose & - \\
22 & lactose & + \\
23 & arabinose & \\
& & Probable identity = Bacillus sp. \\
& NA= Nutrient agar; '+' Positive; '-'Negative
\end{tabular}

\subsection{Enzyme production}

In this study, the production of alkaline phosphatase was carried out in Erlenmeyer flask containing growth medium. It was incubated at $37{ }^{\circ} \mathrm{C}$ for $2-5$ days in a shaking condition. The enzyme production was analyzed at different intervals; The Bacillus species produced alkaline phosphatases at the middle of the stationary phase of growth $\left(2.20 \mathrm{U} / \mathrm{mg}^{-1}\right.$ enzyme activity and $600 \mathrm{mg}$ of protein concentration). Similar alkaline phosphatase production pattern was reported for Bacillus subtilis enzyme.

\subsection{Purification of enzyme}

The medium containing enzyme mixture was used to various purification steps, at first it was optimized by adding precipitation with 2-propanol. The pellet collected from precipitation was subjected to dialyses and chromatography. It showed $0.28 \mathrm{U} / \mathrm{mg}^{-1}$ enzyme activity and $0.31 \mathrm{mg}$ of protein concentration.

In previous studies, the extracellular alkaline phosphatase was eluted on DEAE-cellulose, after elution the specific activity was increased up to $11 \mathrm{U} / \mathrm{mg}$ and purification \% recovery was found to be $36 \%$ and in case of Bacillus licheniformis studied by Hulett et al. [9], fold purification and yield were found to be 2.4 and $10 \%$, respectively. Yield of Alkaline phosphatase are dependent on the strain of bacteria used [21]. This may be the reason for the difference between our results and those reported earlier. One unit of phosphatase is the amount which hydrolyzes $1 \mu \mathrm{mol}$ of substrate per minute at $\mathrm{pH} 8.8$ and temperature $37^{\circ} \mathrm{C}$.

\subsection{Molecular Mass Determination}

The molecular mass of extracellular alkaline phosphatase from Bacillus species was analysed by $10 \%$ acrlamide gel electrophoresis. As alkaline phosphatase found in both diameric and monomeric forms, in this study, only single band was found approximate molecular weight of $54.5 \mathrm{Kda}$ (Fig.1). The diameric forms of alkaline phosphatase produced by E. pyrococcus abyssi with a molecular mass of $54 \mathrm{KD}$ have been previously reported [22]. The SDS-PAGE of B. stearothermophilus alkaline phosphatase showed a single protein band of 32KD [2].

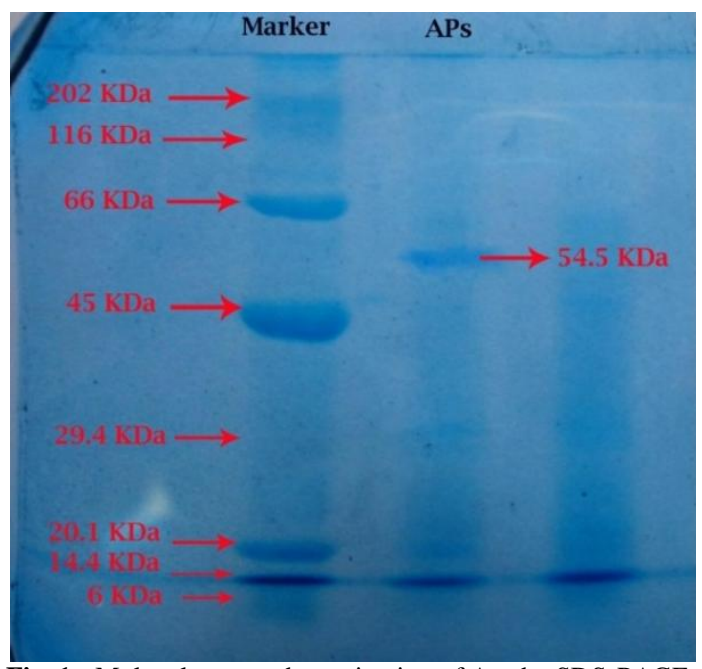

Fig. 1: Molecular mass determination of Aps by SDS-PAGE.

\subsection{Enzyme Characterization}

\subsubsection{Effect of $\mathrm{pH}$}

Effect of $\mathrm{pH}$ on enzyme activity was studied on different $\mathrm{pH}$ ranges $4-11$. In this study, the optimum enzyme activity was found to be higher at $\mathrm{pH} 10.0$. This result is supported by [14] who studied Anthrobactor Strain for extracellular production of alkaline phosphatase. As the $\mathrm{pH}$ increases the decrease in enzyme activity was observed and only $30 \%$ activity was noted at $\mathrm{pH} 11$. Increase in $\mathrm{pH}$ effect the charges on the amino acids within the active site such that the enzyme is not to be able to form enzyme substrate complex. Thus, there is decrease in enzyme activity [23].

\subsubsection{Effect of Temperature}

Effect of temperature was studied on enzyme activity by incubating on different temperatures $20^{\circ} \mathrm{C}-70{ }^{\circ} \mathrm{C}$ per 10 minute. The observation showed that the enzyme is thermostable, as the temperature increased the activity of enzyme also increased and enzyme showed its optimum activity at $60{ }^{\circ} \mathrm{C}$ and became reduced at $60^{\circ} \mathrm{C}$ and $70^{\circ} \mathrm{C}$, similar to the values reported for A. caespitosus [24] and Rhizopus microspores [25]. It shows that the higher temperature increase the kinetic energy of molecules which break the bond that holding the active amino group and enzyme gets denatures. Hence, results in the loss of enzyme activity [26].

\subsection{Effect of Inhibitors and Metal ions}

At $1 \mathrm{mM}$ concentration, the activity of alkaline phosphatase enzyme was inhibited by $\mathrm{K} \& \mathrm{Mg}$ ions and enhanced by $\mathrm{Fe} \& \mathrm{Ca}$ ions, in these $\mathrm{Ca}$ was found to be higher. The result indicates that the enzyme is metallo-dependent. Alkaline phosphatase classically considered to be $\mathrm{Zn}^{2+}$ and $\mathrm{Mg}^{2+}$ dependent, especially, in Escherichia coli and mammalian alkaline phosphatase [27]. The studies of effect of metal ions on alkaline phosphatase activities in Bacillus sp. suggested that there is strong interaction between metal ions and enzyme as alkaline phosphatase may have several metal binding sites. These results are consistent to those of reported earlier [28]. 


\section{CONCLUSION}

In our studies, the alkaline phosphatase shows its optimum activity at $\mathrm{pH} 10$ and temperature $60{ }^{\circ} \mathrm{C}$, which indicate that the enzyme is thermostable. Apart from higher temperature, the thermostable enzymes are also known to withstand denaturants of extremely acidic and alkaline conditions. These enzymes are highly specific with inherent stability and thus, have considerable potential for many industrial and commercial applications. This present investigation emphasized on the need of more research to be carried on Bacillus species to produce extracellular alkaline phosphatase.

\section{REFERENCES}

1. Holander VP. Acid Phosphatases. In: Enzymes. P.D. Boyer (Ed.) Academic Press, NewYork. 1971; 450-498.

2. Mori S, Okamoto M, Nishibori M, Ichimura M, Sakayama J, Endo H. Purification and characterization of alkaline phosphatase from Bacillus stearothermaphilus. Biotechnol. Applied Biochem. 1999; 29: 235-239.

3. Rina M, Pozidis C, Mavromatis K, Tzanodaskalaki M, Kokkinidis M, Bouriotis V. Alkaline phosphatase from the Antarctic strain TAB5. Properties and psychrophilic adaptations. Europian Journal of Biochemistry. 2000; 267: 1230-1238.

4. Torriani A. Alkaline phosphatase subunit and their dimerization in vivo. Journal Bacteriology. 1968; 96: 1200- 1207.

5. Friedberg I, Avigad G. Some properties of alkaline phosphatase of Ps. flourescens. Europian Journal Biochemistry. 1967; 1: 193-198.

6. Wolfenden R, Spence G. Depression of phosphomonoesterase and phosphodiesterase activities in Aerobacter aerogenes. J. Biochim. Biophys. Acta. 1967; 46: 296-298.

7. Takeda K, Tsugita A. Phosphoesterase of B. subtilis. II crystallization and properties of alkaline phosphatase. Journal of Biochemistry. 1967; 61: 231-241.

8. Michaeliss, Beckwith J. Mechanism of incorporation of cell envelope proteins in Escherichia coli. Annual Review of Microbiology. 1982; 36: 435-465.

9. Hulett FM, Stuckmann K, Spencer DB, Sanopoulou T. Purification and Characterization of the Secreted Alkaline Phosphatase of Bacillus licheniformis MC14: Identification of a Possible Precursor. Journal of General Microbiology. 1986; 132: 2387-2395.

10. Hydrean C, Ghosh A, Nallin M, Ghosh BK. Interrelationship of carbohydrate metabolism and APase synthesis in Bacillus licheniformis 759/C. Journal of Biological Chemistry. 1977; 252: 6806-6812.

11. Glew RH, Heath EC. Studies on the extracellular alkaline phosphatase of Micrococcus sodonensis: Isolation and characterization. J. Biol. Chem. 1971; 246:1556-1565.

12. Kobori H, Taga N. Extracellular alkaline phosphatase from marine bacteria: purification and properties of extracellular phosphatase from a marine Pseudomonas sp. Can. Journal of Microbiology. 1980; 26:833-838.

13. Nomoto M, Ohsawa M, Wang HL, Chen CC, Yeh KW. Purification and characterization of extracellular alkaline phosphatase from an alkalophilic bacterium. Agric. Biol. Chem. 1988; 52:1643-1647.
14. Prada PD, Jennifer LC, Jean EB. Production of Two Extracellular Alkaline Phosphatases by a Psychrophilic Arthrobacter Strain. Applied and Environmental Microbiology. 1996; 62 (10):3732-3738.

15. Hulett FM, Wangt P, Sussman M, Lee JW. 1985. Proc. Natl. Acad. Sci. USA, Biochemistry, 82, 1035-1039.

16. Mahesh M, Guleria Neha, Rajesh TS, Somashekhar R, Puttaiah ET. Isolation and characterization of extracellular thermostable alkaline phosphatase enzyme from Bacillus spp. International Journal of Applied Biology and Pharmaceutical Technology. 2010; 1(1).

17. Lowry $\mathrm{OH}$, Rosebrough NJ, Farr AL, Randall RJ. Protein measurement with the Folin-Phenol reagents. J. Biol. Chem. 1951; 193: 265-275

18. Kostadinova S, Marhova M. Purification and properties of alkaline phosphatase from Bacillus cereus second balkan conference on biology special edition/online 2010 .

19. Laemmli UK. Cleavage of structural proteins during the assembly of the head bacteriophage T4. Nature. 1970; 227: 680-685.

20. Steubing PM. 1993. Isolation of an unknown bacterium from soil. In: Tested studies for laboratory teaching. C. A. Goldman (Ed). 14: 81114. Proceedings of the 14th Workshop/Conference of the Association for Biology.

21. Sayer PD. Production of alkaline phosphates from E.coli in continuous culture. Applied Microbiology. 1968; 16(2): 326-329.

22. Robert RB, Evan RK. Characterization of a monomeric E.coli alkaline phosphatase formed upon a single amino acid substitution. J. Biol. Chem. 2003; 278: 23497-23501

23. Hulett FM, Campbell L, Purification and properties of an alkaline phosphate of B. licheniformis. J. Biochem. 1971; 10: 1364-1371.

24. Guimaraes LHS, Terenzi HF, Jorge JA, Leone FA Plizeli MLTM. Extracellur alkaline phosphatase from the filamentous fungus Asperigillus caespitosus: Purification and Biochemical characterization. Folia Microbiology. 2003; 48: 627-632.

25. Junior AB, Guimaraes LHS, Terenzi HF, Jorge JA, Leone FA, Plizeli MLTM. Purification by chemical characterization of thermostable alkaline phosphatases produced by Rhizopus microspores var. rhizopodiformis. Folia Microbiology. 2008; 53(6): 509-516.

26. Bryan LW, Keith W. 1981. General principles of biochemical investigation. Principles and techniques of practical biochemistry. (2nd ed):32-34.

27. Kim EE, Wyckoff HW. Reaction mechanisn of alkaline phosphatase based on crystal structures. Twometal ion catalysis. Journal of Molecular Biology. 1991; 218: 449-464.

28. Goldman S, Hecht K, Eisenberg H, Mevarech M. Extracellular Ca2+dependent inducible alkaline phosphatase from the extremely halophilic archaeabacterium Haloarcula marismortui. J. Bacteriol 1990; 172: 7065-7070.

\section{How to cite this article:}

Suganya K., Ravikumar V. and Murugan T. Production and Characterization of Alkaline Phosphatase Produced by Bacillus Species. J App Biol Biotech. 2015; 3 (05): 031-034. DOI: 10.7324/JABB.2015.3506 